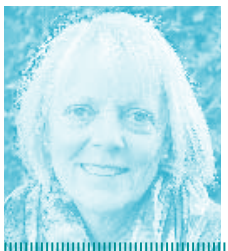

Kirsten Vistnes, høyskolelektor, Høgskolen i Oslo og Akershus, Institutt for helse, ernæring og ledelse

\section{FAG \\ Sykepleierutdanning}

Vivi Graff av Øhr,

praksiskoordinator,

Høgskolen i Oslo og

Akershus

\title{
Samarbeid gir god praksis
}

\author{
Et godt samarbeid mellom høyskole og praksissted er viktig for å utdanne funksjonsdyktige sykepleiere.
}

$\mathbf{A}$ kershus universitetssykehus (Ahus) tar årlig imot cirka 440 sykepleiestudenter i praksis, om lag 300 av disse er i kirurgisk og medisinsk divisjon. Behovet for praksisplasser er økende. Sykehus og høyskole har ulike roller og skal bidra forskjellig når det gjelder undervisning og veiledning av studenter, og bør ha felles mål om å gjøre sykepleierutdanningen best mulig.

Bachelorutdanning i sykepleie innebærer cirka 50 uker praksis. Dette utgjør cirka halvparten av den treårige utdanningen. Rammeplan for sykepleierutdanningen stiller detaljerte krav i forhold til både innhold og lengde av de ulike praksisperiodene. Utdanningene og praksisstedene må legge til rette slik at den enkelte praksisperioden blir meningsfull for studentene. Utdanningen skal gi studentene handlingskompetanse og handlingsberedskap innenfor mange områder. Vi erfarer at studentene mener at den delen av utdanningen som foregår i praksisfeltet er den viktigste.

\section{Hovedbudskap}

Artikkelen viser at både forberedelse til og samarbeidet i praksisperioden mellom praksis, høyskole og student er avgjørende for å legge til rette for god kvalitet og læring i studentenes praksisperiode.

\section{Nøkkelord}

Les mer og finn litteraturhenvisninger på våre nettsider. ) Praksisstudie, Utdanning /Veiledning
En studie av læringsbarrierer for sykepleiestudenter i klinisk praksis, viser at mange studenter opplever at manglende systematisk opplegg for læring på avdelingene er en stor barriere (1). Dette bekrefter inntrykket fra hverdagen i medisinsk og kirurgisk divisjon på Ahus. Fagutviklingssykepleiere og ledere ser at dagens opplegg for studentene bør samordnes bedre og at innholdet kan forbedres.

\section{Samarbeidsprosjekt}

Ved Universitetssykehuset i Akershus ble det høsten 2011 iverksatt to prosjekter i samarbeid med daværende Høgskolen i Akershus, ett i medisinsk divisjon og ett i kirurgisk divisjon. Prosjektene ble iverksatt ved hjelp av høyskolens samarbeidsmidler.

Hensikten med disse to prosjektene var å bidra til bedre kvalitet og organisering av praksisstudiene, samt å se på hvordan man kan legge til rette for å øke antall praksisplasser i framtiden. Prosjektet på medisinsk divisjon har sett på organisering og oppfølging av studenter i praksis. Prosjektet på kirurgisk divisjon har sett på forberedelse til og mottak av studenter i praksis.

For å sikre god planlegging av og kontroll på begge prosjektene ble det satt ned en felles styringsgruppe, ledet av assisterende direktør ved kirurgisk divisjon. I styringsgruppa satt også en representant for høyskolen og for kirurgisk og medisinsk divisjon. De to prosjektene hadde hver sin prosjektgruppe ledet av hver sin prosjektleder, som er fagutviklingssykepleiere i hver sin divisjon. I prosjektgruppene satt det sykepleiere fra praksis og representanter fra høyskolen. Prosjektene hadde en referansegruppe med ressurspersoner fra sykehuset, høyskolen og studenter.

\section{Organisering av praksis}

En vanlig organiseringsmodell er at hver student skal forholde seg til en kontaktsykepleier i hver praksisperiode. Dette er et system med både fordeler og ulemper. En ulempe er at det begrenser antallet studenter praksisstedet vil ta imot. En annen ulempe er at studentene får se lite til hverandre fordi de ofte går i ulike vakter. Modellen har klare fordeler hvis student og sykepleier har en god kontakt og sykepleieren har interesse for veiledning og er en god rollemodell (2).

En annen modell er at en større gruppe studenter veiledes av en gruppe sykepleiere. Dette gir studentene mulighet for å støtte og lære av hverandre gjennom praksisperioden. Fungerer studentene bra kan de etter hvert få flere sykepleieoppgaver, og fungere nesten som sykepleiere med en god støtte i bakhånd mot slutten av studiet (3).

\section{Fremmer læring}

Fra læringspsykologien og stressteorier vet vi mye om hva som hemmer og fremmer læring (4). Faktorer som hemmer læring kan for eksempel være engstelse, opplevelsen av å ikke bli sett, mangel på kontroll, stress og andre former for mistrivsel og utrygghet. Faktorer som fremmer læring kan være trygghet, mestring, kontroll og motivasjon (5). Jensen skriver i sin avhandling om verdien av studenters fellesskap. Hun har studert deltidstudenters utvikling av læring og identitet i praksisfellesskapet. Kunnskapsproduksjonen skjer ved at de ulike deltakerne deltar med ulike bidrag som sammen danner en forståelse av helheten (6).

\section{Ulike modeller}

På Høgskolen i Buskerud har det vært gjennomført prosjekter med studentdrevet post (6), og på 


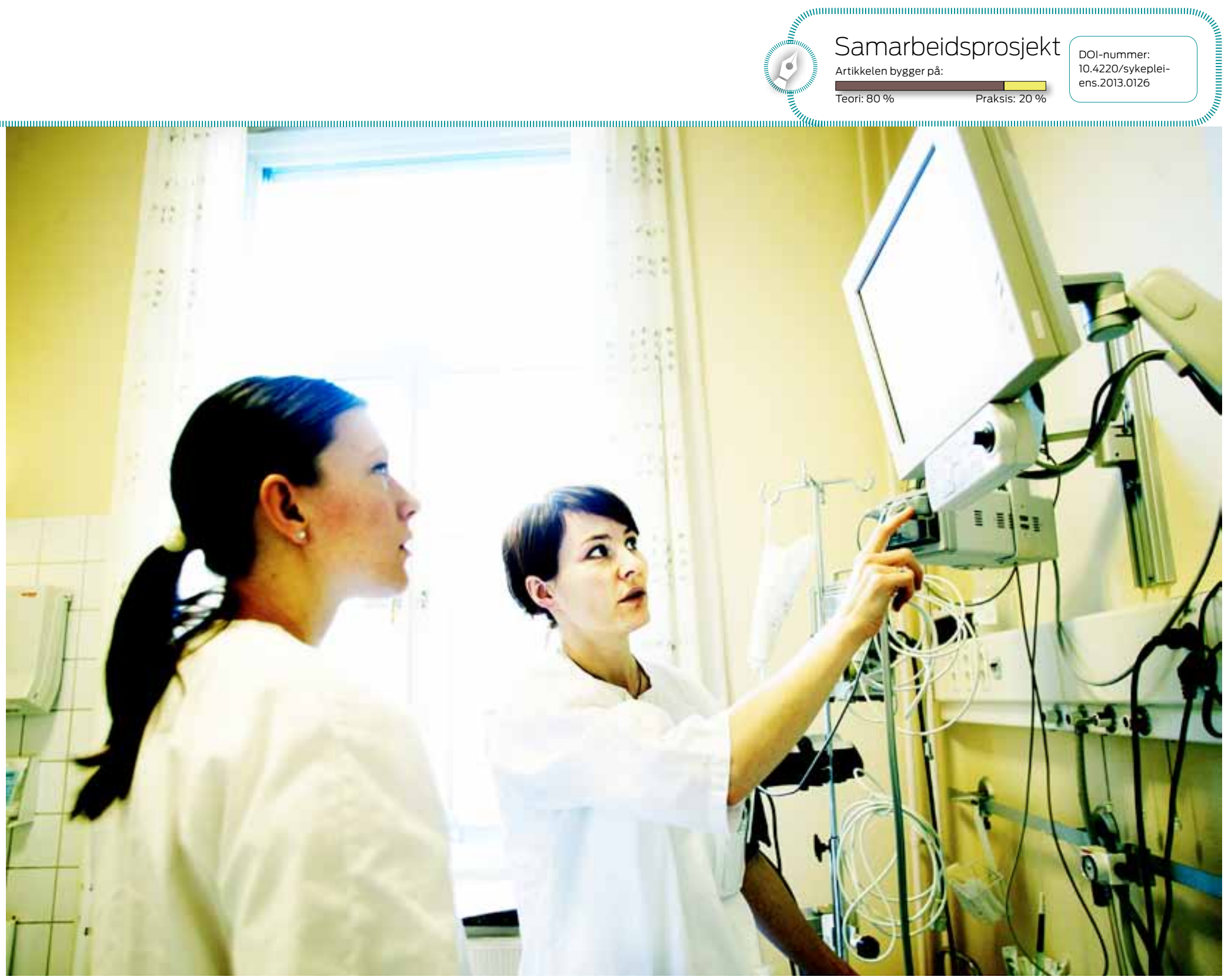

ULIKE MODELLER: Den vanligste organiseringsmodellen for studenter i praksis er at hver student skal forholde seg til en kontaktsykepleier, men det finnes også andre modeller der studentene går i tospann eller team. Arkivfoto: Bo Mathiesen

Diakonhjemmets høgskole har det i flere år vært studentdrevet team på sykehuset (3). Alle prosjektene tar utgangspunkt i det å ha mange studenter på ett praksissted. Ved Høgskolen i Oslo og Akershus har det vært gjennomført ulike prosjekter med mange studenter på sykehjem (8), studentpost på sykehus (9) og prosjekt D04, der et helt kull fikk største del av utdanningen i praksis $(10,11)$. I dette prosjektet ble begrepet fagteam innført, det vil si at studenter, sykepleiere og lærer møtes ukentlig til undervisning og veiledning.

Ved Høgskolen i Gjøvik ble en alternativ praksismodell presentert i 2003, hvor man hadde mange studenter på ett praksissted og vektla studentenes ansvar for egen læring (12). Denne modellen ble lansert som en alternativ praksismodell sammenliknet med den tradisjonelle kontaktsykepleiermodellen. Planen var å innføre modellen på flere av høyskolens praksissteder. En oppfølgingsartikkel sammenlikner de to modellene og presenterer en studie som beskriver midtveisvurderingen i den alternative praksismodellen (2).

Den såkalte tospannmodellen, der to og to stu- denter går sammen i praksis, ble utprøvet ved Høgskolen i Buskerud (13). Også ved Høgskolen i Østfold bruker man tospannmodellen. På noen av praksisstedene er det flere tospann, slik at det blir en gruppe studenter. Høyskolen har også tverrfaglige tospann som er satt sammen av en sykepleiestudent og en vernepleiestudent.

\section{Prosjekt medisinsk divisjon}

Her var hensikten å beskrive arbeidsmetoder og formalisere samarbeidet om studentoppfølging mellom høyskole og sykehus. Ulike modeller for oppfølging av studenter og prosedyrer i tilknytning til disse ble beskrevet som verktøykasser.

Prosjektet startet med en kartlegging. Alle sengeområder ble bedt om å fylle ut et skjema med spørsmål om hvordan studentene ble organisert og fulgt opp. Ut fra dette har prosjektgruppa kommet frem til en beskrivelse av fire ulike veiledningsmodeller:

I En-til-en kontakt,

, To-til-en kontakt,

, Tospann

I Studenttett tun eller team.

\section{Prosjekt kirurgisk divisjon}

Ved kirurgisk divisjon var hensikten å gjøre studentene bedre forberedt til praksisperioden, og bedre selve mottaket av studentene. Alle de kirurgiske sengeområdene ble bedt om å presentere seg med pasientgruppe(r), diagnoser, prosedyrer

\section{«Vi vet at studentene lærer best når de får gjøre reelle sykepleieoppgaver.»»}

og rutiner. Man utarbeidet studenthefter med felles forventninger for alle sengeområdene. Dette materialet ble i neste omgang lagt ut på høyskolens læringsplattform (Fronter) slik at studentene fikk tilgang. På denne måten kunne studentene bli kjent med de ulike sengeområdene og forberede seg i forkant av praksis. Her ligger også kontaktinformasjon, slik at det er enkelt for studentene å finne navn og mailadresser til studentansvarlige ved sengeområdet. Sidene oppdateres minst en gang per år. 


\section{Sykepleierutdanning}

Eksempel på verktøykasse:

Sjekkliste til bruk ved studenttett tun/team

Send studentenes egenpresentasjon til gruppa

Lag et program for veiledningsmøter (fagteam) med studenter, lærer og en eller flere sykepleiere fra gruppa

Koordiner at sykepleiere fra gruppa kan være med på fagteammøtene

Turnuskriterier: Studentene skal dekke opp alle vakter. Det må lages turnus til antall studenter, med utgangspunkt i turnusene til sykepleierne igruppa, eller bruke vedlagte mal

Studentene skriver ukelogg/refleksjonsnotat

Lag program for forventnings- og vurderingsmøter
Kryssav Ansvar

Kommentar
Fagutviklingssykepleier*

Disse bør ha tidligere erfaring med studenter tene (fanger opp både dag- og kveldsvakter). Legge inn både veiledning (ansvar: lærer) og undervisning fra sykepleiere (evt. fra student el. lærer)

Koordinerer og har ansvar for fagteamprogram og vurdering

Vedlegg: eksempel på oppsett av studentturnus, åtte studenter i åtte uke

Fagutviklingssykepleier*

Daglig eller ukentlig, kommenteres av sykepleier

Lærer isamarbeid med fagutviklingssykepleier*
Midtveisvurderingen skal alltid være individuell

*Fagutviklingssykepleier eller den som har studentansvar ved sengeområdet

\section{Resultat}

Prosjektet på medisinsk sengeområde har ført til en bevisstgjøring av hvilke forutsetninger som må være til stede når man velger modell for oppfølging av studenter. Verktøykassa som er laget er et nyttig hjelpemiddel til dette. Vi ser også at det enkelte sengeområdet må finne sin måte å organisere på, det må være en viss fleksibilitet rundt de ulike modellene. Alle sykepleiere på området må oppleve et eierskap til den valgte modellen, og ikke at en modell blir valgt av ledelsen uten å involvere de ansatte som skal ha den daglige kontakten med studentene.

Prosjektet i kirurgisk divisjon har sikret studentene gjennomarbeidet og lik informasjon, uavhengig av praksissted. Evaluering etter oppstart er udelt positiv, studentene har hatt stor nytte av informasjonen på Fronter og mener det gjør dem bedre forberedt før oppstart i praksis. Prosjektet blir nå innført også i medisinsk divisjon.

\section{Konklusjon}

Studentens læring i praksis er kompleks og avhengig av mange faktorer. Disse faktorene viser seg i stor grad å være avhengig av hverandre og kan skisseres ved hjelp av en trekant:



Kristin Heggen betegner overgangen til høyskolesystemet som frihet fra å delta i sykepleierens oppgaver satt opp mot frihet til å delta i utøvelsen av sykepleie (14). Denne overgangen kom allerede da sykepleiestudentene gikk over til å bli høyskolestudenter med de rettigheter det innebærer. Samtidig vet vi at studentene lærer best når de får gjøre reelle sykepleieoppgaver. Dette blir en balansegang som både skole og praksis må være klar over, og lage klare avtaler om.

Disse prosjektene på Ahus har vist betydningen av et godt samarbeid mellom høyskole og praksisfelt. Vi har jobbet sammen og lært av hverandre. Praksisperiodene er ikke noe som overlates til praksisstedet, og teoriperiodene bør også inkludere sykepleiere fra praksis. Bare på den måten kan vi lykkes i å utdanne gode og funksjonsdyktige sykepleiere. IIII
REFERANSER

. Kjersheim MD. Learning Barriers in Clinical Nursing Practice. Hovedoppgave, $\mathrm{UiO}, 2005$.

2. Bjerkvold MP, Myhren AB, Hedelin B. Sykepleiestudenters erfaringer med midtveisvurdering i alternativ praksismodell. Norsk tidsskift for sykepleimidtveisvurdering i alternativ pra

3. Wisløff EMS. Studentdrevet team som læringsarena. Oslo: Diakonhjemmets Høgskole, 2006.

4. Lazarus R, Folkman S. Stress, Appraisal and Coping. New York: Springer, 1984.

5. Berntsen K, Bjørk IT. Nursing students` perceptions of the clinical learning environment in nursing homes. J Nurs Educ. 2010 Jan; 49(1): 17-22.

6. Jensen KT. A være student i en feltbasert utdanning. Avhandling til graden dr.polit. Universitetet i Oslo, 2006.

7. Jenssen U, Onshuus K. Studentdrevet post. Et samarbeidsprosjekt mellom Drammen kommune, omsorgstjenestene Strøms $ø$ og Høgskolen i Buskerud, avd. helsefag, 2003.

8. Onstad RF. Økt ansvar og selvstendighet for sykepleiere i praksis på et bo- og behandlingssenter. FOU- rapport, Høgskolen i Akershus, Avdeling for sykepleierutdanning 1997.

9. Gulpinar S, Johnsen HN. Studentposten S4, tilrettelegging, gjennomføring og evaluering. Rapport, Høgskolen i Akershus, Avdeling for sykepleierutdanning, 2003.

10. Sortland K. The Competence Reform in Nursing Education. I: Holmesland, Icara da Silva, Lundin, Judy Deanne (Eds). Formal and Informal Learning: Shall the Twain Ever Meet in Adult Education? Akershus: Forskningsserie, Høgskolen i Akershus, 2009: 67-99.

11. Jerpseth H. Ny sykepleierutdanning, med arbeidsplassen som læringsarena. Høgskolen i Akershus, Avdeling for sykepleierutdanning, 2007.

12. Bjerkvold MP, Myhren AB, Sørlie K (2003). Alternativ praksismodell: Et samarbeidsprosjekt mellom sykehuset Innlandet, Gjøvik og Høgskolen Gjøvik, avd. helsefag. Tidsskriftet Sykepleien 2003; 17: 39-42.

13. Slettebø $\AA$, Bryn V, Hovdsveen R, Veitsle K, Syvertsen A. Hjemmesykepleien: Praksisstudier i tospann. Sykepleien forskning 2009; 1: 44-50.

14. Heggen K. Sykehuset som "klasserom". Praksislæring i profesjonsutdanningene. Oslo: Universitetsforlaget, 1995.

Fagartikler kan sendes til torhild.apall@sykepleien.no 